\section{Preoperative beta- blockade for patients undergoing craniotomy: a comparison between propranolol and atenolol}

Richard A.W. Allberry MB BS FFARCS, Helen F. Drake, MB BS FFARCS
This study was undertaken to establish if beta-blocking drugs given orally before surgery could reduce the pressor responses to laryngeal instrumentation and tracheal intubation in neurosurgical patients. Forty-two neurosurgical patients undergoing craniotomy were randomized into three groups. Groups I and 2 received atenolol ( $100 \mathrm{mg})$ and propranolol $(80 \mathrm{mg})$ respectively. Group 3 were controls and given no beta-blockers. A standard anaesthetic technique was used and blood pressure and heart rate were measured continuously from induction of anaesthesia until five minutes after tracheal intubation. There were increases in both heart rate and systolic blood pressure in all three groups but the rises in the treated groups were significantly less than in the control group $(P<0.01)$. There were no significant differences in the haemodynamic responses between the propranolol and atenolol treated patients.

Cette étude fut entreprise afin d'établir si les bêta-bloqueurs oraux avant la chirurgie peuvent diminuer l'hypertension due ì l'instrumentation laryngée et l'intubation trachéale en neurochirurgie. Quarante-deux patients devant subir une craniotomie ont été randomisés en trois groupes. Les groupe 1 et 2 ont reçu de l'aténolol (100 mg) et du propranolol $(80 \mathrm{mg}$ ) respectivement. Pour le groupe 3 (contrôle) aucun bêta-bloqueur ne fut administré. Une technique anesthésique standard fut utilisée et la pression artérielle et la fréquence cardiaque furent mesurées continuellement à partir de l'induction de l'anesthésie jusqu'à

\section{Key words}

ANAESTHESIA: neurosurgical;

COMPLICATIONS: cardiovascular, hypertension, tachycardia;

INTUBATION, TRACHEAL: complications;

SYMPATHETIC NERVOUS SYSTEM: beta-adrenergic antagonists, propranolol, atenolol.

From the National Hospital for Nervous Diseases, Queen Square, London, WCI.

Address correspondence to: Dr. Richard A. W. Allberry, Department of Anaesthesia, St Thomas' Hospital, London, SEI 7EH, United Kingdom. cinq minutes après l' intubation trachéale. On nota une auginentation de la fréquence cardiaque el de la pression artérielle systolique chez tous les patients des trois groupes mais celle augmentation chez les groupes traités était significativement moindre chez le groupe contrôle $(P<0.01)$. Il n'y avait aucune différence significative dans les réponses hémodynamiques entre propranolol et aténolol chez ces patients.

Laryngoscopy and tracheal intubation have been shown to elevate blood pressure and heart rate. 'In neurosurgical patients this pressor response increases the risk of rupture of intracranial aneurysms and arterio-venous malformations $^{2,3}$ and may cause an increase in the intracranial pressure. ${ }^{4}$ This study was undertaken to determine whether the addition of preoperative oral beta-blockade attenuated this pressor response.

\section{Methods}

Following approval by the Hospital Ethical Committee, 42 patients undergoing craniotomy (ASA Physical Status I-III), between 18 and $65 \mathrm{yr}$, and requiring peroperative intra-arterial blood pressure monitoring and tracheal intubation, were randomized into one of three groups. The details of the operative procedures are given in Table I. None of the patients was operated upon in the sitting position. Patients with contraindications to the administration of beta-blocking drugs were excluded from the study, as were those receiving any anti-hypertensive therapy. All groups received dexamethasone $8 \mathrm{mg}$ and ranitidine $50 \mathrm{mg}$ IM one hour before surgery. In addition, Group 1 received atenolol $100 \mathrm{mg}$, and Group 2, propranolol $80 \mathrm{mg}$ orally two hours preoperatively.

Prior to induction of anaesthesia, the ECG was monitored (CM5 electrode), and a radial artery was cannulated under local anaesthesia. The ECG and arterial blood pressure were continuously monitored (Roche 128), and recorded (Lectromed MX216) from induction of anaesthesia until five minutes after tracheal intubation. The arterial blood pressure was referenced to the right atrium. 
TABLE I Demographic data and types of operative procedure

\begin{tabular}{|c|c|c|c|}
\hline & \multicolumn{3}{|l|}{ Group } \\
\hline & $\begin{array}{l}l \\
\text { Alenolol } \\
n=15\end{array}$ & $\begin{array}{l}2 \\
\text { Propranolol } \\
n=13\end{array}$ & $\begin{array}{l}3 \\
\text { Control } \\
n=14\end{array}$ \\
\hline Mean age (SEM)/yr & $47.3(3.8)$ & $46.9(3.5)$ & $49.7(3.7)$ \\
\hline Mean weight (SEM) $/ \mathrm{kg}$ & $69.5(2.8)$ & $67.8(2.5)$ & $72.9(3.3)$ \\
\hline Male & 10 & 6 & 7 \\
\hline Female & 5 & 7 & 7 \\
\hline Supra-tentorial tumours & 12 & 9 & 14 \\
\hline Posterior fossa tumours & 3 & I & - \\
\hline Vascular lesions & 1 & 2 & 3 \\
\hline
\end{tabular}

Anaesthesia was induced with the technique which was standard for these patients in this hospital. No precurarizing drugs were given. Anaesthesia was induced with thiopentone $5 \mathrm{mg} \cdot \mathrm{kg}^{-1}$ and muscle relaxation obtained with succinylcholine $1.5 \mathrm{mg} \cdot \mathrm{kg}^{-1}$. The patients' lungs were then ventilated manually with oxygen and nitrous oxide (50:50) and one per cent isoflurane, inspired, via face mask. Laryngoscopy was performed, and the larynx sprayed with $2 \mathrm{ml}$, four per cent lidocaine, followed immediately by the introduction of a flexometallic oro-tracheal tube. Only one attempt at intubation was made in each of the study patients. Immediately after intubation, mechanical ventilation was commenced using the same concentration of anaesthetic agents with a minute volume of $100 \mathrm{ml} \cdot \mathrm{kg}^{-1}$, and a tidal volume of 10 $\mathrm{ml} \cdot \mathrm{kg}^{-\mathbf{l}}$.

Heart rate, and systolic and diastolic blood pressures were recorded before and during the induction of anaesthesia, and every $15 \mathrm{sec}$ after intubation for $15 \mathrm{~min}$. The maximum heart rate and systolic blood pressure were also noted.

Statistical evaluation of the results was by analysis of variance of the post-intubation maximum values of systolic blood pressure and heart rate, allowing for the starting values as covariates. The within-group changes were analysed by unpaired $t$ tests.

TABLE II Maximum systolic blood pressure after intubation

\begin{tabular}{|c|c|c|c|}
\hline \multirow[b]{2}{*}{$\begin{array}{l}\text { Systolic pressure } \\
\mathrm{mmHg}\end{array}$} & \multicolumn{3}{|l|}{ Group } \\
\hline & $\begin{array}{l}l \\
\text { Atenolol } \\
n=15\end{array}$ & $\begin{array}{l}2 \\
\text { Propranolol } \\
n=13\end{array}$ & $\begin{array}{l}3 \\
\text { Control } \\
n=14\end{array}$ \\
\hline Mean starting (SEM) & $168(5.2)$ & $166(7.2)$ & $167(4.4)$ \\
\hline $\begin{array}{l}\text { Mean maximum (SEM) } \\
\text { Mean maximum (SEM) }\end{array}$ & $183(7.0)^{*}$ & $188(7.7)^{*}$ & $216(7.4)$ \\
\hline (adjusted for initial SBP) & $182(6.4)^{*}$ & $189(6.8)^{*}$ & $216(6.6)$ \\
\hline
\end{tabular}

*P<0.01 compared with control.

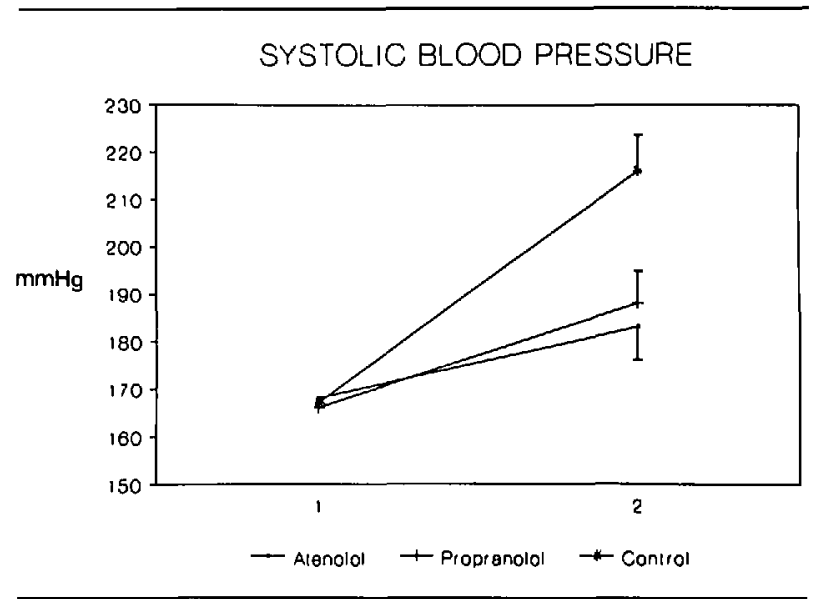

FIGURE I Pre- (1) and maximum post-intubation (2) systolic blood pressures (SEM) in patients for craniotomy.

\section{Results}

Patient details are shown in Table I. There were no differences in the demographic data among the three groups.

No differences were found in the pre-induction systolic blood pressure, but the initial heart rate was significantly lower in both treated groups $(P<0.01)$.

The maximum post-induction systolic blood pressures in the three groups are illustrated in Table II and Figure 1. The patients in the control and propranolol groups showed a significant increase in systolic blood pressure, but the rise in the atenolol group was not significant. The difference between both treated groups and the control group was highly significant ( $F=7.45$ ), though there was no significant difference between the two treatment groups.

The maximum heart rate following induction of anaesthesia in the three groups is shown in Table III and Figure 2. All three groups showed significant rises, but those in the atenolol and propranolol groups were significantly less than that in the control group $(F=13.15)$. Again there was no significant difference between the two treatment groups.

TABLE II] Maximum heart rate after intubation

\begin{tabular}{|c|c|c|c|}
\hline \multirow[b]{2}{*}{$\begin{array}{l}\text { Heart rate } \\
\text { beats } \cdot \mathrm{min}^{-1}\end{array}$} & \multicolumn{3}{|l|}{ Group } \\
\hline & $\begin{array}{l}l \\
\text { Alenolol } \\
n=15\end{array}$ & $\begin{array}{l}2 \\
\text { Propranolol } \\
n=13\end{array}$ & $\begin{array}{l}3 \\
\text { Control } \\
n=14\end{array}$ \\
\hline Mean starting (SEM) & $60(3.1)$ & $59(2.0)$ & $75(4.5)$ \\
\hline Mean maximum (SEM) & $80(2.7)^{*}$ & $81(3.1)^{*}$ & $112(5.1)$ \\
\hline $\begin{array}{l}\text { Mean maximum (SEM) } \\
\quad \text { (adjusted for initial HR) }\end{array}$ & $87(3.8)^{*}$ & $88(4.2)^{*}$ & $111(3.3)$ \\
\hline
\end{tabular}

$* P<0.01$ compared with control. 


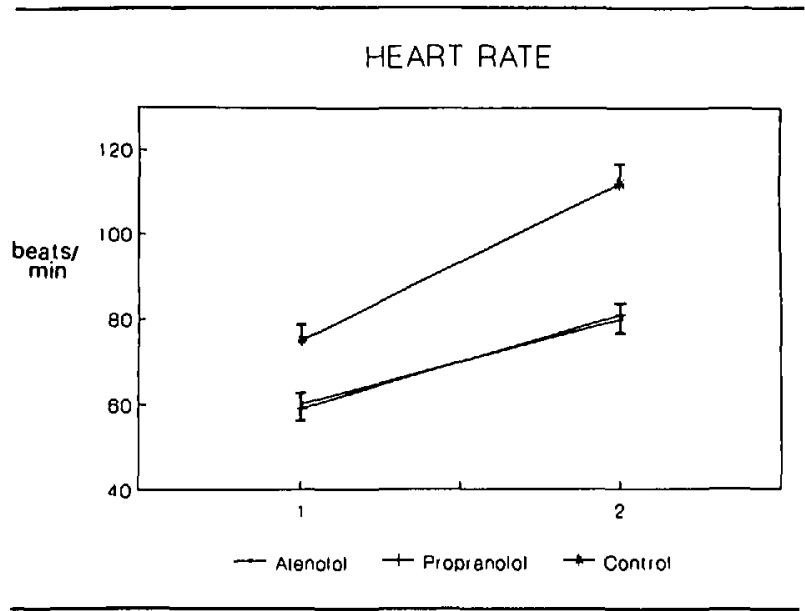

FIGURE 2 Pre- (1) and maximum post-intubation (2) heart rate (SEM) in patients for craniotomy.

No side effects attributable to the use of either atenolol or propranolol were recorded.

\section{Discussion}

Laryngeal instrumentation and tracheal intubation have been shown to increase systolic blood pressure and heart rate in humans. In certain situations this may be deleterious to the patient, including those patients with compromised left ventricular function or ischaemic heart disease. 5

Patients with cerebral pathology may also be at risk from pressor responses during laryngoscopy and tracheal intubation. Burney and Winn ${ }^{4}$ demonstrated an increase in intracranial pressure in response to laryngoscopy and tracheal intubation in 14 patients undergoing craniotomy or carotid angiography using a similar induction sequence to that used in this study. Fox et al. ${ }^{2}$ have reported a case in which laryngoscopy and tracheal intubation in a treated hypertensive patient were followed by fatal rupture of a cerebral aneurysm. The tachycardia associated with tracheal intubation may lower the cerebral perfusion pressure by decreasing the mean arterial pressure and cardiac output, and furthermore may cause excessive haemorrhage if an aneurysm is ruptured.

It therefore seems reasonable to attempt to reduce the haemodynamic effects of laryngeal instrumentation in neurosurgical patients. A variety of techniques has been used in previous studies. These include topical and parenteral local anaesthetic agents, ${ }^{6,7}$ alpha-adrenergic blocking drugs, ${ }^{8}$ opiates ${ }^{9}$ and nitrates. ${ }^{10,11}$ However, it is believed that the response is mediated through the beta sympathetic nervous system, ${ }^{12}$ and several studies have shown that the response can be attenuated using intravenous beta-blockers including practolol, ${ }^{13,15}$ metoprol- ol, ${ }^{14}$ esmolol $^{15}$ and labetolol, ${ }^{13,15}$ which has combined alpha- and beta-blocking effects.

The present study used two beta-blockers, propranolol and atenolol, given orally two hours preoperatively. These two drugs differ widely in their pharmacology; propranolol is largely protein-bound (93 per cent), noncardioselective and may readily cross the blood-brain barrier. It is well absorbed from the gastro-intestinal tract but its bio-availability may be limited by first pass hepatic metabolism especially in starved patients. Atenolol is largely cardioselective, is only 20 per cent protein-bound, and only a small fraction crosses the blood-brain barrier. Both drugs reach their peak effect two hours after oral administration and have a plasma half-life of five to eight hours. The doses used were approximately equipotent.

Our results show that both drugs in a single oral dose given two hours before induction of anaesthesia will attenuate the pressor and heart rate responses to tracheal intubation. The effects on the response to laryngeal instrumentation are therefore similar to those reported by previous investigators using adrenergic beta-blockers to reduce the haemodynamic consequences of tracheal intubation. The advantages of a single oral dose of the beta-blocking drug include simplicity of administration, and safety for the patient. Many of the previous studies involved prolonged infusions of beta-blockers preoperatively or, alternatively, the use of an intravenous bolus at the time of induction of anaesthesia. This latter method may involve a sudden decrease in arterial blood pressure or heart rate which may compromise cerebral perfusion in patients with raised intra-cranial pressure. Furthermore, the attenuating effect of oral propranolol and atenolol was seen without the use of a sedative or analgesic pre-medication which might have moderated the rise in heart rate or blood pressure, although propranolol ${ }^{17}$ and oxprenolol ${ }^{18}$ have been shown to reduce the peripheral manifestations of stress.

In summary, this study showed that a single oral dose beta-blocking agent attenuated the haemodynamic responses to laryngoscopy and tracheal intubation. The method used was simple, safe, predictable and acceptable to patients. Although we found no significant difference between propranolol and atenolol, cardioselectivity may favour the latter in the presence of reactive airways disease.

\section{Acknowledgements}

We are grateful to Dr. Doreen Jewkes and Dr. Nicholas Hirsch of the National Hospital for Nervous Diseases for their help in the preparation of this paper, and to Miss S. Chinn of St Thomas' Hospital for statistical advice. 


\section{References}

I King BD, Harris LC, Griffenstein FE, Elder JD, Dripps $R D$. Reflex circulatory responses to direct laryngoscopy and tracheal intubation performed during general anesthesia. Anesthesiology 1951; 12: 556-66.

2 Fox E, Sklar GS, Hill G, Villaneuva $R$, King BD. Complications related to the pressor response to endotracheal intubation. Anesthesiology 1977; 47: 524-5.

3 Normes $H$, Wikeby $P$. Results of microsurgical management of intracranial aneurysms. J Neurosurg 1979; 51 : 608-14.

4 Burney $R B$, Wimn $R$. Increased cerebrospinal fluid pressure during laryngoscopy and intubation for induction of anesthesia. Anesth Analg 1975; 54: 687-90.

5 Prys-Roberts C, Greene LT, Meloche R, Foex P. Studies of anaesthesia in relation to hypertension. 11. Haemodynamic consequences of induction and endotracheal intubation. Br J Anaesth 1971; 43: 531-47.

6 Stoelting $R K$, Peterson $C$. Circulatory changes during anesthetic induction: impact of d-tubocurarine pretreatment, thiamylal, succinylcholine, laryngoscopy and tracheal lidocaine. Anesth Analg 1976; 55: 77-81.

7 Abou-Madi M, Keszler H, Yacoub O. A method of prevention of cardiovascular reactions to laryngoscopy and intubation. Can Anaesth Soc J 1975: 22: 316-29.

8 Devault $M$, Grieffenstein FE, Harris $L C$. Circulatory responses to endotracheal intubation in light general anaesthesia - the effect of atropine and phentolamine. Anesthesiology 1960; 21:360-2.

9 Martin DE, Rosenberg H, Aukburg SJ et al. Low-dose fentanyl blunts circulatory responses to tracheal intubation. Anesth Analg 1982; 61: 680-4.

10 Fassoulaki $A$, Kaniaris $P$. Intranasal administration of nitroglycerine attenuates the pressor response to laryngoscopy and intubation of the trachea. $\mathrm{Br} J$ Anaesth 1983; 55: 49-52.

11 Karma S, Wig J, Sapru RP. Topical nitroglycerine - a safeguard against pressor responses to tracheal intubation. Anaesthesia 1986; 41: 1087-91.

12 Derbyshire DR, Chmielewski A, Fell D, Vater M, Achola $K$, Smith $G$. Plasma catecholamine responses to tracheal intubation. Br J Anaesth 1983; 55: 855-9.

13 Maharaj RJ. Thompson M, Brock-Utne JG, Williamson R, Downing JW. Treatment of hypertension following endotracheal intubation. S Afr Med J 1983; 63: 69I-4.
14 Magnusson J, Thulin T, Werner O, Jarhult J, Thomsom $D$. Haemodynamic effects of pre-treatment with metoprolol in hypertensive patients undergoing surgery. $\mathrm{Br} \mathrm{J}$ Anaesth 1986; 58: 251-60.

15 Cucchiara RF, Benefiel DJ, Matreo RS, Dewood M, Albin $M S$. Evaluation of esmolol in controlling increases in heart rate and blood pressure during endotracheal intubation in patients undergoing carotid endarterectomy Anesthesiology 1986; 65: 528-31.

16 Fischler $M$, Dubois $C$, Broadary $D$ et al. Circulatory responses to thiopentone and tracheal intubation in patients with coronary artery disease. Br J Anaesth 1985; 57: 493-6.

17 Brantigan TA, Brantigan CO, Joseph NJ. Beta-blockade and musical performance. Lancet 1978; 2: 896.

18 James IM, Pearson RM, Griffiths DNW, Newbury P. Effect of oxprenolol on stage-fright in musicians. Lancet 1977; 2: 952-4. 